\title{
The impact of Trade Agreements on Agriculture Sector, Import and Export: Albanian Case
}

\section{Mergleda Hodo}

\author{
Epoka University, Tirane/Albania \\ mhodo@epoka.edu.al
}

\section{Doi:10.5901/jesr.2014.v4n4p421}

\begin{abstract}
This study examine the impact of Albanian free trade agreements on the overall economy in general and in agriculture sector, exports and imports in particular, turning out to be increased in significant amounts. These trade agreements have provided the Albanian economy with a competitive advantage and economic space. Among the countries with which Albania has free trade agreements Turkey, Kosovo, Croatia, Macedonia can be mentioned. This means free exchange of goods and services between these countries by exploiting better their competitive advantages. The possibility of the development of agro-industrial industries continues to be high for Albania, because many products can be exported customs duty zero, facilitating the burden of tariffs and taxes. All analyses done about the impact of the FTA on trade facilitation, price reduction and the volume of imports and exports results that generally in 2008 and especially since 2010, there has been seen a positive trend in the increase of the volume of trade, indicating the positive effect of these agreements in the mentioned sectors. Furthermore, there is a need for deep structural changes, including changing the size of the farm, further development of the land market, increased competitiveness, more domestic production, and an increase the level of public and private investments in the future.
\end{abstract}

Keywords: Agriculture, exports, imports, tariffs, customs duty, impact

\section{Introduction}

As Albania is one of the developing countries, it can be said that agriculture is one of the most important sectors of the economy. It contributes about 30 to 60 percent to the overall economy. Large segments of population are employed in this segment, ranging from 40 to 90 percent. When a trade relation is signed between countries, especially between the developing ones like Albania, the main items that are exported include agricultural items. And once these items are traded, a high contribution is given to agricultural sector. In studying the international arena and Albanian agro-industrial sector integration, it's implied the Analysis of the exports and imports of agro products, the problems of it, what are its needs and the process of integration of this sector in the international trade. The positive impact of Free Trade Agreements of Albania is reflected deeply in imports and exports, providing an increased supplementation with market needs, promoting more the import of goods and services that are difficult to find in Albania. Prices are reduced, also taxes are reduced, which promotes economic competition and boosting of production to be traded associated with improvements in technology for facilitating trade. The amount of exports is increased due to the facilitation of free movement of goods and services with no customs duties or with reduced tariffs. Trade exchange opportunities are increased between Albania and other countries, increasing the trade of industrial and agricultural products that are subject to reduction in customs duties. These agreements aim at achieving step by step liberalization, open up the markets between each other and open up trade between them. Economic development and prosperity are also among their most important aims.

\section{Albania's Trade}

Albania is an import-oriented economy where the export base remains small, narrow, and undiversified, due mainly to a lack of price competitiveness, poor infrastructure, and a challenging business environment. According to the estimates of the Ministry of Finance, the trade deficit continues to extend and reached 26\% of GDP for 2008, up from 23.3\% in 2006. In the end of 2009, Albania trade deficit amounted to 327,668 million ALL and increased only by $0.3 \%$ as compared to 2008. During the 2009, exports volume have confirmed and deepened the negative trend of 2008. According to the 2009 statistics, Albanian Total exports in 2009, amounted to 103.438 million ALL and decreased by $8.1 \%$ as compared to 2008. Also, Albania was the 143rd exporting country in the world. During the first half of 2009 has concentrated the most important decrease of exports. The third quarter of the year represented a stop in the decline trend and exports figures achieved almost the same levels as in the same period of 2008. The slight recovery in October was followed by an 
improvement during the last two months of 2009, where December represented the most successful month for all 2009 with an increase of $41 \%$, as compared to the same month of 2008.

\subsection{Low volume of exports}

A variety of factors influence the quantities of exports that are supplied and demanded, the more goods and services will be produced for export the higher the real return on exporting, relative to returns from other uses for the resources used in exporting. The supply of and demand for export volumes are influenced by the exchange rate and in the same time some firms may have the ability to charge 'different' prices to the norm. This is correlated with the degree to which a product is differentiated from other products. On the contrary, dairy products and most agricultural commodities are comparatively undifferentiated, and their prices are determined in world markets. The low level of exports is affected by many factors such as the energetic crisis which has had an important impact on all economic sectors profitability and be one of the reasons why the Albanian economy has not exploited the domestic capabilities adequately. The domination of very small agriculture unit with a very little production of market, the domination of small workshops mainly with old equipment with just regional importance and so cannot fulfill the conditions of the European market, the difficulties of small producers organizing to collect the adequate amounts of production, the lack infrastructure and weak marketing to improve the image for tourism development, lack of capital to invest on modern equipment, the production levels are lower than the aimed countries etc.

In order to increase the export, there are many conditions to be fulfilled by all suppliers aiming to get the control of a part of these markets like hygienic standards, product presentations supply continuity etc.

\section{Crisis is Challenged by Agro-Industry}

The only industries that increased in times of crises were agro-food and agricultural industry. In order to enhance the presence of agricultural products in foreign markets, their quality and standards have been increased. Great improvements have been seen in the exports of eggs, vegetables, sea products, medicinal plants and fruits. After so many years, for the first time more products are issued in the market, increasing in this way the food industry operations. Total exports of agro industry have been around 6.6 billion in 2011, which means they have increased by $35 \%$ compared to 2010. A greater dynamism in activity characterized this sector, compared to 2009-2010, years in which Albanian industrialists were very pessimistic about the effects of the international financial crisis.

Figure 1. Agro -product exports-imports in Albania

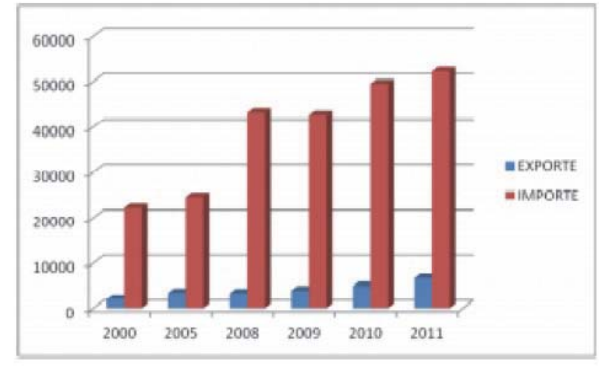

More entrepreneurs have turned their eyes from investment in agro industry, at a time that crisis had affected trade, construction and many other sectors. Among reasons behind the improvement of the agricultural sector, there can be mentioned the increased quality and taste of products, cheap labor and improved standards in accordance to the ones of the EU. In year 2011-2012 floods had a positive effect on the export of vegetables and fruits, thus the demand for these items increased.

Albania exports towards foreign markets about 54.9 percent of the total agricultural exports for 2011, meaning that these exports have increased by 35\% compared to one year ago. (Ministry of Agriculture and Food). An increase by $12 \%$ has been noted in exports of agro-industrial products, in the first six months of 2010 in comparison to the first six months of 2011. The countries of Eastern Europe, including here Albania have signed many agreements for free trade with the 
EU and the Agreement "CEFTA", which gives them a great opportunity to develop agro-industries, because of the 0 customs duties at which products can be exported.

Sea food products grew by $10.2 \%$, which makes up a great percentage in exports of Albanian agro industry. The main countries with which Albania has exported are Italy, Greece and Germany Regarding exports with Kosovo, there has been noticed a positive trend, because of the improved infrastructure, the new road Durres-Kukes-Morine and Albanian population. But regarding exports with the United States, it can be said that they occupy just a little percentage, including organic products and medicinal plants mainly.

\subsection{Exports and its most potential sectors}

Albania is relatively competitive on some agro-industrial and agricultural products. Seafood, eggs, organic products, essential oils, fish, medicinal plants, vegetables, fruits, milk and milk products, are some of the main products that are traded, exported by Albania to the other countries.

\subsubsection{The eggs exports raise}

Among the most potential sectors for export it can be mentioned the eggs industry. About 50 percent of the productions is exported to Kosovo, Greece, Italy and Croatia. Comparing agriculture exports of egg production in the first months of 2012 with the first months of 2011, there is a change of 275\% (Ministry of Agriculture, 2012). Sales in the foreign markets have increased since 2006, when Albania won the right to export to foreign markets. The only two companies in Albania that are given the right of exporting eggs to the European Union markets are Floryhen and Aiba, because they're the only companies that meet the requirements set by Europe. Various food productions use Albanian egg industries. They say that there are facilities in exporting and income generated is high because of the high prices and easy distribution, and the facility in the collection of payments.

\subsubsection{The exports of medicinal plants increase}

The products that are said to benefit more than other products in the European market are teas and herbs, or medicinal plants. The potential of medicinal herbs export was potentially low, but recently, there has been noticed a positive trend towards their export. In year 2011, the export of medicinal herbs reached 8780 tons, equivalent to 2.2 billion lek, which is 22.7 percent more than in 2010.

Table 1.The volume of total exports under the FTA and expressed in tons

\begin{tabular}{|c|c|c|c|c|c|}
\hline 2008 & & 2009 & & 2010 & \\
\hline Total Ton & FTA Ton & Total Ton & FTA Ton & Total Ton & FTA Ton \\
\hline $1,687,884$ & 306,898 & $1,566,457$ & 93,947 & $2,657,652$ & 255,004 \\
\hline
\end{tabular}

Figure 2 - Volume of Exports in Ton, Total and FTA

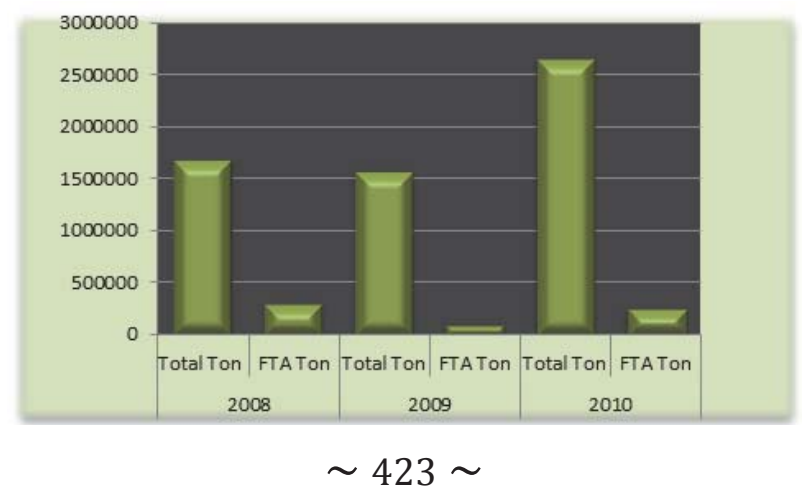


According to figure 1, 2008 has been the year in which the largest amount of exports has been reached, while in 2009, exports fell by $7 \%$ in comparison to 2008 calculating in total tons, and $69,3 \%$ calculating in total tons under the FTA. In 2010, exports increased by 70 percent compared to 2009 and by $57 \%$ compared to 2008 . Whereas under the FTA, a $171 \%$ increase was seen comparing with 2009 and a 16.9\% decrease comparing to 2008 .

Table 2. Volume of Exports in mln leks, Total and MTL

\begin{tabular}{|c|c|c|c|c|c|}
\hline 2008 & & 2009 & & 2010 & \\
\hline Total Value/mln leks & FTA Value/mln leks & Total Value/mln leks & FTA Value/mln leks & Total Value/mln leks & FTA Value/mln leks \\
\hline 112,572 & 10,326 & 103,214 & 2,242 & 161,009 & 12,104 \\
\hline
\end{tabular}

Figure 3- Volume of Exports in mln leks, Total and MTL

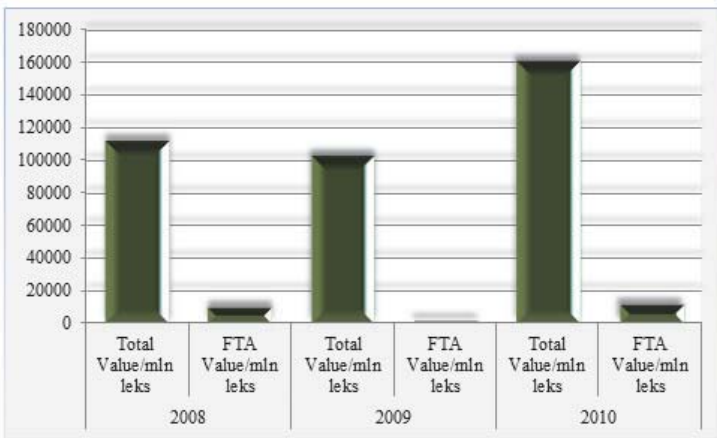

According to figure 2, a decrease of 8.3 percent is shown in comparison of the total 2008. And in year 2009, a 60 percent increase is noted in comparison to 2009 and 43 percent increase in comparison to 2008. Expressed in lek, according to FTA, all tests show that in 2009, a 78 percent decrease is seen, while compared to 2009, in 2010 a 440 percent increase is seen, and compared to $2008,17.2$ percent increase.

\subsubsection{Flour Industry}

The largest share in the sector of agro industry is occupied by flour industry. The impact on economy growth has been very positive. Flour production in year 2011 was 7.5 percent higher than in 2010 (Ministry of Agriculture). The major number of businesses in the agro-industry are bakeries.

There are some reasons for restricting Albanian exports such as

$\checkmark$ Insufficiency and low levels of agricultural production and agro-processing industry;

$\checkmark$ Lack of marketing services (storage, processing, packaging of products);

$\checkmark$ Low standards on food safety;

$\checkmark$ Low degree of competition in the Albanian market of agricultural products because of low

$\checkmark$ Feature and relatively high cost of Albanian products.

\section{Conclusions}

In this research paper, it is analyzed the impact of FTA on the facilitation of trade for Albania, resulting in price reduction and an increase in the volume of imports and exports. In recent years it is seen a great attention to the implementation of free trade with the countries of the region, because it boosts the volume of exports of goods produced in Albania. While regarding agriculture, it's revealed that it's a sector to which a high priority is given in recent years. Despite the economic crisis, the agriculture department keeps growing. Incomes from agriculture are not very high in comparison to European Countries, but competitiveness is boosted because the quality of agro-food products is increased. A high priority is also 
given to the export of these products, because of the integrated management of productions systems. Domestic productivity has reached a significant improvement, almost in all the sectors, but specifically in the agriculture sector, which consequently increases the export of agriculture related goods. The removal of taxes on export and import of agricultural machinery, equipment and goods, has lead to technological improvement and rapid growth in the volume of imports and exports. Flour industry is developed, also the export of eggs, and the export of medicinal plants. All these achievements in the Albanian economy are due to its free trade agreements with the countries of the region and with the European countries. They have had an extremely positive effect on the developing sectors of the economy, and on the sectors that make up the most of Albanian economy.

It's through international fairs that our Albanian products can be recognized in the countries of the region and in the European Union countries. The Ministry of Tourism can help through stands and make this mission possible. In order to increase the exports towards European Union countries, Albania must consolidate the land market, which can be achieved through an increase of information in farmers' hands by brochures of different services. And in order to increase the agricultural products export, it's recommended that Albania raises the domestic productivity, by increasing state subventions for farmers, high standards and quality of the domestic produced goods, guarantees for products in the sector of agriculture, and to monitor sanitary and veterinary situation. The institutions that are responsible for creating independent laboratories should be committed to this responsibility.

\section{References}

Agreements. (n.d.). Retrieved from http:/lec.europa.eu/trade/policy/countries-and-regions/agreements/ David, \& Ervin, (1997). Agriculture, trade and the environment: Anticipating the policy challenges.

Florinda Dema (2013) "Impact of agreement trade in development Albania's agricultural.

Frankel, Jeffrey, \& David, R. (1997). Trade and growth: An empirical investigation. Secretariat for the Convention on Biological Diversity Montreal.

Irma Tabaku (2009) "Albania and Trade Liberalization Using our trade advantages in the Free Trade Agreement with EU" 113th EAAE Seminar "A resilient European food industry and food chain in a challenging world", Chania, Crete, Greece, date as in: September 3 - 6, 2009

Impact of free trade agreements between Albania and the countries of the region in the volume o imports and exports for the years 2008 2010. (n.d.). Retrieved from http://www.theglobaljournals.com/ijar/file.php?val=MjAxMw

Stilian, A., (2008). Agriculture economy. 